\title{
Developing christian education by utilizing the conceptions of pluralist- multicultural value
}

\author{
Demianus Ice ${ }^{1}$ \\ ${ }^{1}$ Christian Religion Education program, Faculty of Theology-Halmahera University \\ * demianus.ice20@gmail.com
}

\begin{abstract}
Christian-pluralist-multicultural education is a practice (applied) of theoretical studies that are textual (consist of ideals) of the scriptures, normative theological, pedagogical, philosophical, and the values of local cultural wisdom into Christian Education practices. The purpose of this research is to develop a pluralist-multicultural Christian education in the pluralistic context of North Maluku. To achieve the objective, this research uses qualitative research methods with data collection techniques of participatory observation, in-depth interviews, document studies, and focus group discussions. The subjects in this research are religious leaders who are members of the North Maluku religious community forum (FKUB) and educators who are determined using purpose sampling technique. Data and research findings were analyzed using interactive data analysis techniques to obtain the true meaning. The results of this study found out a conception of a pluarist-multicultural in Christian education in the context of education in North Maluku. There are several themes of research findings from the results of critical dialogue between facts and theory, namely (1) the vision and mission of developing Christian education in pluralist-multicultural perspective; (2) the aims of Christian education in pluralist-multicultural perspective; (3) the elaboration of the objectives of Christian education in pluralistmulticultural perspective; (4) the content of Christian education in pluralist-multicultural perspective; (5) the characteristics of the content of Christian education in pluralist-multicultural perspective; (6) Christian education learning methods in pluralistmulticultural perspective.
\end{abstract}

Keywords

Pluralist, multicultural, value, christian education

Article Received: 20 September 2020, Revised: 30 November 2020, Accepted: 18 December 2020

\section{Introduction}

The reality of the plurality of religions, ethnicities, cultures and social conflicts in the 16th century is part of previous events, which we do not discuss here. Because the Christian-Islamic encounter and social conflicts that occurred in the 16th century were closely related to ethnic plurality and social conflicts that occurred long before that. Then, we also need to remember that before the 16th century, which we recorded as the beginning of the Christian-Muslim encounter, there was an encounter between Islam and tribal religions in the 13th century. (Haire, 1998). From the perspective of managing social conflict because of the differences in diversity, we must pay close attention to all of these. However, because we do not talk about conflict from a historical perspective, this research will emphasize at the urgency of the need for Christian education by utilizing the pluralist-multicultural perspective. The historical records shown earlier only attempt to draw the threads of the conflict that occurred in 1999-2003 with its historical roots.
The North Maluku Christian-Muslim social conflict began in August 1999 in Kao Halmahera Utara, then continued to Tidore, Ternate, and returned to Halmahera in general and Tobelo in particular; the most devastating of all the previous incidents was 26 December 1999 onwards. The tragic events that have passed are inseparable from the historical context of the religious and social life of the adherents of these two religions in particular, and the life of the nation in general. At first this conflict was related to the struggle for territory between ethnic groups, but later it was expanded by using religious sensitivity or fanaticism by parties who wanted to take advantage of the situation. Like the previous conflicts, which occurred in several historical chapters above, the 1999-2003 social conflict claimed a lot of lives and property. There are many influencing factors which we can mention in this research. In the following social analysis, we will get a broad depiction of what factors come into play.

The empirical facts above are not enough for us to recognize the social conflicts that have occurred. 
We need a social analysis in order to find a more complete picture of these social conditions. This means that the social conflict between Muslims and Christians in North Maluku must be placed within a broader framework. Therefore, in the following discussion there will be a description and analysis of the influencing factors. In addition to the narrow and closed understanding of religions of scripture, theology and teachings (exclusivism), the author will also describe other factors that put an impact directly and indirectly. In other words, to understand an event such as the North Maluku social conflict, there are many elements that we need to know and many models of approaches that we need to consider in making interpretations of social conflict as social change that is happening.

Psychologically, the victims of the riots experienced deep psychological trauma. This is the result of armed conflict, in which children experience persistent disturbances, while adults experience acute stress, depression, panic and anxiety. Symptoms of this trauma can be seen in various forms of post-conflict community life. There are those who withdraw themselves and don't want to hang out anymore, there are those who behave not according to their age, being argumentative, defiant behaviour, tend to act tough on anyone who hurts their feelings, and so on. To find out whether someone has Post Traumatic Stress Disorder or not, we need to recognize three sets of symptoms, namely: (1) reexperiencing a traumatic event (reexperiencing), (2) feeling frozen or numb (numbing or avoidance of reminders) and (3) being overly alert or physically and emotionally susceptible (hypervigilance or hyperarousal). These three categories of symptoms commonly appear in behavior which include aspects of a person's thoughts, feelings, and actions, such as: always remembering past tragic events, difficulty concentrating on certain thought directions, experiencing eating disorders, sleeping disorders, oversensitive, tempramental, rude, fearful, sad, guilty, feel sorry to avoid talking about events or places that are reminiscent of tragic things that they have been seen. All these disorders have a very negative effect on social interactions in the family, society and the wider environment
(Judowibowo Poerwodidagdo, 2003). Therefore, post-conflict reconciliation efforts must be supported by an analysis that takes into account of psychological assumptions like this so that pastoral planning and social action can take place proportionally, effectively and efficiently.

Sociologically, there is a very wide social distance. It is true that Islam and Christianity have lived together, but here and there, there is still a sense of suspicion, distrust between one group and another. Its social conditions are still far from what we expect a Christian education to be. We still need to work hard to restore these social relationships in accordance with new ideals and hopes that are much better than the previous life.

From this social analysis we have a broad picture of social reality. That religious pluralism, social conflict due to the inability to manage differences and poverty due to social injustice are the social realities of North Maluku that we must address. In other words, whatever policies we take to raise the human status of the people of North Maluku, must be based on existing social realities.

As a part of constructive pastoral action to answer post-conflict social problems. Within this framework, the right pastoral action is to develop Christian education in the context of a multicultural-pluralist society.

\section{Methods}

The method used in this research is qualitative. The qualitative method is considered the most appropriate because the focus of the problem and the characteristics of the research subject must be approached by using qualitative data collection techniques. Because the focus of the problem in this study is related to the understanding of subjects related to Christian education with a pluralist-multicultural perspective, the most appropriate data collection techniques are interviews, participatory observation, document studies, and focus group discussions. With the technique used, the key instrument in this study is the researcher, and other instruments used by the researcher are interview guides, observation 
guides, document study guides, and focus group discussions. (Bungin, 2006).

The data analysis technique used is interactive data analysis techniques as suggested by Milles and Huberman (Creswell \& Creswell, 2017); (Nebraska-Lincoln \& 2009, ). The results of this interactive data analysis serve as the basis for the researcher in constructing or developing a Christian-pluralist-multicultural education model by using a research and development approach. The development that is needed in this research is still hypothetical which has not been statistically tested for its effectiveness.

\section{Results and Discussion}

\section{Vision and Mission of Christian Education Based on Pluralist-Multicultural Value in North Maluku}

The vision of Christian education in North Maluku is inseparable from the church's vision in the struggle for the social context of religious plurality in Indonesia. As an institution that bear the authority to organize Christian Education, of course GMIH has a vision of Christian Education which is directed at the question: what generation does the church long for as a result of the learning process of Christian-pluralist-multicultural Christian Education; or theologically, ethically, socio-Christian, what quality of life is predicted by the church in a good and systematic way through Christian Education. This is a question or statement describing what profiles of cognitive, affective and psychomotor competencies or abilities that must be possessed by educators personally, their families, teachers, the environment or the faith community as the target of Christian Education.

The vision of Christian Education is in line with the vision of the GMIH which was formulated in the XXVII GMIH Synod Session "GMIH INTEGRATED, INDEPENDENT AND MISSIONARY". From the perspective of the internal context of the church, this vision was born in the reality of the social conflict in North Maluku which resulted in the intactness of the GMIH in terms of the physical administration, as well as the organism, being scattered. Meanwhile, externally, the integrity of relations with others (Muslims) was in a serious crisis. From a philosophical point of view, this vision idealizes a condition of "reconnecting the ties of friendship that have been damaged by conflict". And from a theological-pedagogical point of view, this vision idealizes a comprehensive thinking insight in relation to the understanding of church members about the reality of religion plurality.

In relation to how to build a Christian-pluralistmulticultural education (religious plurality and other diversity), a vision like this is very important for GMIH. Besides giving direction to the life of the church, it is also first of all so that there is awareness or pluralist-multicultural insight from the educator, that North Maluku is the 'home' of all religions, ethnicities, languages, dialects and a number of human cultures that inhabit the islands. Thus, the narrator will realize that the religion they adhere to is only one of the existing particularities. Starting from the above premise, the characteristics of the Christian education theory that the writer will show below are more of a convergence of the two, namely pluralistmulticulturalism. This is an educational effort in increasing the perspective of human religious thinking as a cultured creature, so that through a systematic and planned learning process, our educators are enabled to develop social attitudes: mutual acceptance, respect and support for diversity. In other words, the characteristics of Christian education that the researcher presented in this chapter are not purely religious pluralism (pluralist), but they are accumulated in what is called by the Christian-pluralist-multicultural education. Tilaar said, multicultural education is actually "an attitude of caring and willingness to understand (difference), or 'politics of recognition', the politics of recognition of people ..." (El-Ma'hady, 2006). Or as Muhamad Ali meant, "pluralist-multicultural education is a process of awareness that composed of pluralist viewpoint (religiously) and at the same time has a multicultural perspective (culturally)" (Muhamad Ali, 2003). 


\section{Objectives of Pluralist-Multicultural Christian Education}

In general, Burgess' socio-cultural theoretical approach to Christian education carries objective aspects that we can apply here. According to him, the goal of Christian education must be related to the social and cultural environment of society. Therefore, the basic aspects of a goal must be determined by social-societal ideals and/or based on the needs of the social and cultural environment, then to be developed by taking into account the following factors: the development of beliefs, experiences, and actual socio-cultural problems. Therefore, the goal of Christian education which tends to maintain the main idea (status quo) needs to be developed creatively and progressively in the sense of reconstructing, redefining and reorganizing the values of religious traditions that are considered irrelevant.

Starting from the aspects of the above goals, according to him, the scope of the goals of Christian education must include all efforts that make God's democracy possible. This democracy is achieved socially along with other members of society. Meanwhile, the moral and social dimensions of the goal depend on the quality (characteristics) of human relations as social beings. To be able to build morals in relationships with fellow human beings in a fair and harmonious manner, an education system that understands the socio-cultural situation in a concrete way is needed (William Burgess, 1975).

Goeroge Albert Coe, one of those who developed this approach, put forward the following goals of creative-progressive Christian education: "Growth of the young toward and into the mature and efficient devotion to democracy of God, and happy self-realization therein" (WilliamBurgess, 1975). He defines the formulation of educational goals by: 1) there is no difference in society (safe and unsafe); 2) obedience to society, not due to a sharp view of separating survivors from unsaved people; 3) the need for a concrete achievement (self-actualization) can be adjusted; 4) individualism (egoism) must be reduced in order to participate in creating an ideal society, only in this way can one realize fellowship with the heavenly Father.

If we relate the aspects of the aforementioned educational goals with the social reality of pluralism and social conflict as religious-socialsocietal problems, then creatively, we can also deconstruct the traditional-conservative Christian educational goals to become more dynamic in our social context. From the main ideas of the aims of Christian education above, we can conclude implicitly that: 1) The aim of Christian education must be to have the character of love for God and fellow human beings; 2) The formulation of the goal of CHRISTIAN EDUCATION must consider the social context or social reality in a broad sense: multicultural-pluralism, poverty, oppression, injustice and other social ills; 3) The goals of creative Christian education must be supported by the assumption of social sciences that are actual / relevant to the real needs in which the learning process takes place; 4) The aim of Christian education must be able to accommodate the interests of the socio-cultural structure of a society; 5) The goal of Christian education must have a tolerant character for a harmonious life together; 6) The goal of Christian education must start from the assumption that the Kingdom of God is in the world and is in progress, therefore the signs can be pursued by the church which bases its preaching on the Kingdom of God.

Within this framework of thinking, and in relation to how to formulate the goals of Christian education in the context of religious, ethnic, cultural and so on, the authors confirm Hope S. Antone with his perspective "mealtable sharing". Antone states that as the "mealtable" model is attractive and fits the Asian context, because all humans need food and life, its educational goals are also attractive because "... addressing many human needs for understanding, reconciliation, healing and justice..." (Antone, 2003). Jeff Smith said: "I am tired of wars and battles based on some sort of assumed misunderstanding. I believe that we will be able to call ourselves truly civilized only when we have more chefs than the soldiers! " (Antone, 2003). So, for Smith "mealtable sharing" is an end to war and conflict 
which of course aims for justice, goodness and peace.

Another aspect of educational goals can be seen in Chun Hyun Kyung's review of pluralism and multiculturalism. Kyung expressed dissatisfaction with pluralism, diversity, multiculturalism, crosscultural understanding of academia, the church and American society. Because they emphasize the "softness" and "laziness" of the issue. What she means is pluralism and multiculturalism related to "... ethnic food, ethnic clothing, ethnic music ..." because for her we can get a "... Chinese breakfast, Italian lunch, and French dinner ..." but we do not reach our politics or economic power.

Actually, Kyung's review is related to global market-influenced consumerism, so the question that arises in this context is: in the invitation to eat, what food is eaten? If the food and drink consumed in the dinner invitation is as viewed by Kyung, is it accommodating for all levels of society who are invited to eat? The researcher understands Kyung's anxiety that this method is less empathic, but tends to be consumeristic. Then what is her view on pluralism? She said, "I think that we have to go beyond pluralism. We need an interdependent, interpenetrating, powersharing, mutual transformation for our common survival and liberation and for the sustainable earth community" (Antone, 2003).

In Indonesia, the aims of Christian education in the context of religious plurality as mentioned above have been struggled. According to Kadarmanto, other goals that are adequate and feasible in addition to sustainable development and other matters as mentioned above are: realizing peace in justice (peace with justice). Efforts to resolve conflicts and relieve tensions cannot be separated from efforts to enforce justice. Peace education, guidance and/or conflictresolution training are things that need to be added to Christian education programs to improve conflict resolution skills. (Kadarmanto, 2002).

From some of the thoughts about the goals of education above, we can conclude that the goal of Christian-pluralist-multicultural education is education which aims to develop sympathy, appreciation and empathy for adherents of different religions and cultures based on Christian values. The emphasis on the goal of Christian education in this perspective points to the values of "Christian compassion" which originate from God (Sitopu, 2004).

\section{Elaboration of The Learning Objectives of Christian-Pluaralist-Multicultural Education}

\section{The Cognitive Area}

In the category of Benjamin S. Bloom's cognitive goals consist of six parts, namely: knowledge, understanding, application, analysis, synthesis, and evaluation (Bloom, 1972). In terms of difficulty level, this cognitive level is contained in the development process of the "thinking" of the narrator with the difficulty level of knowledge characterized in operational words such as: "Remembering-mentioning" goes to "solving problems". This cognitive level is related to the development of the thinking skills of educators in the age categories: children, adolescents, youth, and adults. So, to apply Christian education or describe educational goals into the cognitive realm, we need to pay attention to the assumptions of developmental psychology, so that educational subjects can be adjusted between the needs of the educators, the absorption and the difficulty level of the material presented. That is, according to the ability to think, needs, interests and talents that has been developed at certain stages of development.

Because Christian-pluralist-multicultural education in this research is addressed to educators (students) on campus, the cognitive level referred to here is a higher level, namely analyzing various religious values, making a synthesis of the various theses and antitheses found in exploring religious and cultural values, critically evaluating various information regarding the truths contained in religions to find the main idea of pluralist-multicultural reality, namely the universal truth.

\section{The Affective Area}

The description of the goals of Christian-pluralistmulticultural education in the affective domain 
can be elaborated into elements concerning: tastes, images, emotions, feelings, attitudes, appreciation, values, morals and beliefs that exist in each educator. Part of it is psychological attitudes. Therefore, the psychological characteristics and symptoms in this area are difficult for us to read or monitor in terms of shape, direction and intensity.

Affective goals in the form of behavior change can be seen from simple indicators in the form of "paying attention" to a phenomenon up to complex (difficult) goals regarding a person's internal factors, including those concerning conscience. Even though it is rather difficult to operationalize in the form of behavior changes, in this aspect there are a number of indicators that can describe a person's affective symptoms such as: aspirations and hopes of certain ethnic or religious groups to live together or side by side in peace, wishes and feelings that are manifested or expressed by Christian education in the form of acts of respect, appreciation, support, acceptance of people of different ethnicities and religions based on the norms of love that we profess as a religious person, the aspirations that exist in each person, interests, feelings, beliefs and worries, as well as patterns of actions that we can actively observe.

\section{The Psychomotor Area}

It is not easy to describe the aims of Christianpluralist-multicultural education in this area. Because this field has more to do with psychological factors or attitudes as expressions of soul or feelings, which are materially different from motoric ones in the form of muscle movements: sports, writing, painting, and other fields of technical-physical nature. To elaborate the aims of Christian education into this area a psychological approach will be of great help to us, especially through John Locke's theory of imitation. This theory says that a person's behavior is influenced by the "environment" through association, repetition and imitation (emotional connection to something, repeated experiences and imitating something) (Crain, 1992). This theory is well developed by Albert Bandura in what is called modeling. In this theory he recommends that learning could be done by observing other people and imitating what is witnessed. There are four reasonable factors, said Bandura. First, any specific or unique behavior arouses interest to be observed. Second, every memorable action is recall, remembered. Third, everyone has the potential or tendency to imitate. Fourth, motivation or direction is needed to imitate (Broeree, 2004).

Of course, the model or example referred to here is a good one. For students, the method of learning physical-modeling is relatively easy, they can move to abstract things. For example, it concerns Christian compassionate values that must be studied and imitated or practiced. In relation to something different, this method of learning will be effective because the uniqueness of other religions will be something interesting to learn.

\section{The Life Skill Area}

Life skills, are skills to create or find solutions to new problems (innovation) by using facts, concepts, principles or procedures that have been learned. For example, after studying the concept of Christian-pluralist-multicultural education, the life skill is how the educator maintains good relationships in meeting people of different religions, ethnicities, cultures, languages and other differences, whenever and wherever they are. If they found a problem in the encounter, then their life skill is full of creation and innovation to find solutions so that harmony in life and diversity would be re-created. It is hoped that this skill will enable Christian education to be brave enough to face life's problems without feeling pressured. So, life skill is the ability to reflect properly and accurately under any conditions. This is a real-life learning which requires a reorientation of learning from subject-matter oriented to life-skill oriented.

In a pluralistic social context, we need several skills such as: (1) self-knowledge skills, this skill we need to realize ourselves that we are God's creatures, who are endowed with ratios (intellect) as a very valuable potential to create everything that supports togetherness in life; (2) thinking skills, we need this skills to explore or process information, identify problems in order to make 
decisions; (3) social skills, including the ability to communicate with other people verbally or in writing, as well as being able to cooperate; (4) academic skills, including the ability to identify (recognize) problems, determine academic action properly and wisely (Kristen, 1992). In describing the goals of Christian-pluralist-multicultural education into life skill, basic competencies in the sense of skills like this must appear in the characteristics of the goals.

\section{Determining The Content of Prularist- Multicultural Christian Education}

Christian education in the context of religious plurality and/or multiculturalism is a process that facilitates educators to see themselves and their faith in relation to the context of religious pluralism. Therefore, the content of Christian education cannot be limited to what is called "Judeo-Christian" in the holy scriptures and Christian traditions, but is more dynamic-open to other truths in religions. Russel Candran reminds us that we should be able to read the signs of the times, because for him the world situation is very harsh, not only regarding pluralism in religion, but locally, nationally and globally, our lives are marked by "... cultures, socio-political structures , social conditions, etc "(Candran, 1991).

For this purpose, we actually have to return to the social context of Christian education, because again, as Antone argues, that the social context in which we are in will shape the theory of Christian education. Starting from this assumption, and to maintain the social context of Christian education that the writer described earlier consistently, in the framework of this thesis we do not discuss the world and Asian contexts (in general), but in the social context of local Christian education in North Maluku as a Case. It is quite clear in the researcher's description from the introduction that the social context of Christian education in North Maluku is related to the problem of religious plurality and social conflict. Thus, the scope for determining the content of Christian-pluralistmulticultural education can be created from these conditions.
The social context of Christian education "religious plurality and social conflict caused by various variables", like the authors of the previous analysis, is a question that must be answered with the content of Christian education (content) in accordance with the social context. Thus, based on the understanding of the scriptures, theology and church teachings, as well as other related themes, we need to consider the contents of this course in a thematic form such as: Mapping of Various Religious Attitudes; Pluralism and Multiculturalism in Biblical Perspective, Theology and Teachings; The Reality of Religious Plurality and Local Cultural Wisdom; Christian Social Attitudes in the Context of Religious Pluralism: dialogue, reconciliation, tolerance; Religions and Poverty; and Seeking Communal Truth in a Common Faith Dialogue.

Of course, the above themes or topics are still too general in nature, because it needs to be elaborated in detail in the form of sub-subjects according to the needs and the time available for that. And of course, this will be more interesting if it is studied in a multidisciplinary manner. The following discussion of the characteristics of the content is likely to provide a clearer and better picture for developing these subjects in the perspective of education of religions in general and of Christian education in particular.

\section{Characteristics of The Content of Christiani- Pluralist-Multilcultural Education}

Based on the content of Christian-pluralistmulticultural education as explained in the previous section, the following describes the characteristics of the content of multiculturalChristian-pluralist-education learning.

\section{Learning to Live Different}

The UNESCO Conference in 1998 launched 4 main pillars of the education system, namely: lerning to know, learning to do, learning to be and learning to live together (Hutabarat, 2004). The first pillar has more or less to do with the faculty of reason. This system conditions or stimulates the mind to be able to think, analyze and interpret critically and innovatively. Learning with this 
system allows people not to stop after getting results. Outcomes of learning in this system are actually used as a starting point for further learning activities. Thus, learning becomes an activity that continues to increase, both qualitatively and quantitatively.

The second pillar emphasizes learning how cognitive is improved to a higher domain to the ability to analyze (to know why), linking with other things to get conclusions (synthesize) and finally applying it (learning to do). Learning to know and learning to do are two pillars of the education system that emphasize life skills which are considered incomplete, if they are not supported or balanced with the following pillars (3rd and 4th), namely: learning to be and learning to live together.

The third pillar focuses on exploring personal potential existentially. It is a system which actually cultivates a high level of reason, will, taste and feeling. The learning process with this system allows people to know themselves, develop themselves, plan something, be able to make the right decisions at certain times and be able to project themselves optimally for the future. Therefore, their motivation to learn is not only to obtain a number of information to increase knowledge and skills, but how they develop themselves into a complete and independent person. The learning process with a system like this can occur because of self-awareness when connecting themselves with the surrounding environment.

This system recognizes the potential of humans as social beings, which can only develop well in interaction and communication with others. This system will condition the learning process that prioritizes cooperative relationships or reciprocal relationships between group members with one another and increases social sensitivity or social care. The learning process with this system allows the birth of a global awareness of everything. Here all the nations of the world become one "global" citizen, so that relations between individuals, between locations, between regions, between countries and continents are transparent as if without boundaries. Living in a world like this, patterns of relationships with others also develop due to social changes. If traditionally the relationship with each other was limited to fellow citizens in one country, now the neighbors are citizens of other countries. This situation will break down the boundaries of ethnicity, race, religion and nation as well as bring positive and negative impacts. Those who can survive are those who have a strong foundation of values, especially religious values. In connection with that, the fourth education system (learning to live together) is needed, because this system allows a learning process that is not only scholastic or academic, but also involves the education of universal shared values that grow and are rooted in values and attitudes of religious inclusivism.

According to Baidhawy's observations, conventional education has so far only provided a large portion of the development of three pillars, namely: how to know, how to do, and how to be. Conventional education, according to him, has not fundamentally taught as well as instilled "skills to live together" in a plural community religiously, culturally and ethnically. In relation to pluralistmulticultural religious education, Baidhawy emphasized that the fourth pillar should be given a more adequate portion, namely how to live and work together with others.(Baidhawy, 2005). The way in which this pillar is developed can take place through a process; tolerance, empathy and sympathy; values that guarantee a common life; emotional maturity; equality and participation; and renewal of social contracts.

\section{Building Mutual Trust}

Social conflict not only causes psychological trauma, but also wide social distance, because the two fighting groups are no longer trust each other. For Baidhawy, mutual trust is social capital, analogous to economic capital and symbolic capital, which can be simply defined as "a set of values or informal norms shared by members of a community group that encourage cooperation with one another. (Baidhawy, 2002, 2005; Coward, 1989). This requires honesty, sincerity, and a strong will in convincing people with social behavior that is born from the expression of 
religious values. In that connection, all norms that produce social capital must substantively prioritize truth, meet obligations, and reciprocity.

Such norms, according to him, it can be found in the values mentioned in The Protestant Ethic and the Spirit of Capitalism, by Max Weber. As social capital, we can use these values in analyzing the social conditions of society. Even this social capital can contribute culturally-accumulatively, to facilitate our social tasks in shaping a pluralistic society. In line with this, religion as an important pillar in the formation of culture and ethnicity needs to be careful in internalizing and externalizing scriptures, theology and teachings, because the identification of culture and ethnicity in the name of religion, which is not sensitive to the surrounding environment, will foster "prejudice". between religious groups, which in turn can lead to social conflict. Thus, pluralistmulticultural education must be able to enlighten our educators through the process of developing mutual trust between religions, cultures and ethnic groups. (Baidhawy, 2002, 2005; Coward, 1989).

\section{Maintaining Mutual Understanding}

Knowing or understanding other religions that are different can only develop well if our educators have a good understanding that they are different from other people from earlier. This understanding is drawn from how to recognize things that are visible (physical) and generativeethnic-culture and abstract: religious values and others. If a person goes through the learning process or the willingness to learn something different and mature in it, he will easily know or understand who he is, his ethnicity, culture, religion and environment that are not the same as other people. Therefore, if other people actualize themselves or express certain values they hold, I already have to know or understand that, that is he, that is himself, his ethnicity, his culture, and his religion.

This needs to be straightened out, because some people feel afraid if they try to be manly and in love to understand the other person's point of view. that means they have created the wrong impression that understanding is the realization that their values and ours can be different and may complement each other and contribute to a vibrant and dynamic relationship, so that the opposition is a complementary partner and the partnership brings together partial truths in a relation. So, a true friend is a dialogue opponent who is always loyal to accept differences and is ready for all possibilities to find common ground in them, and understands that in differences and similarities, there are uniqueness that cannot be shared by participants in a partnership. For this reason, pluralist-multicultural Christian education must take this responsibility in building an ethical foundation of mutual understanding between plural religious and cultural entities, as a shared attitude and concern. (Baidhawy, 2002, 2005; Coward, 1989).

\section{Upholding The Attitude of Mutual Respect}

This attitude or expression of religious values must be placed in the theology of creation, that all humans are created by God, have the same degree, and are cared for by the Creator in the one place that He made, namely the earth with the essence of food and drink. This attitude places all human beings in equality, without superiority and interiority. Appreciate and respect each other are universal values embodied by all religions in the world. Thus, religious education and more specifically Christian-pluralist-multicultural education is a management of Christian values that fosters awareness that peace between religious adherents is a voice raised by lord leaders and us as followers, so that we can and are ready to hear the voice. (perspective) other different religions; respect the significance and dignity of all diverse religious individuals and groups. In other words, to maintain honor and dignity, we do not have to sacrifice the honor and dignity of others, moreover by using means and acts of violence. Mutual respect will lead to mutual sharing among all individuals and groups (Baidhawy, 2002, 2005; Coward, 1989).

\section{Upholding The Attitude of Mutual Respect}

This attitude or expression of religious values must be placed in the theology of creation, that all humans are created by God, have the same degree, 
and are cared for by the Creator in the one place that $\mathrm{He}$ made, namely the earth with the essence of food and drink. This attitude places all human beings in equality, without superiority and interiority. Appreciate and respect each other are universal values embodied by all religions in the world. Thus, religious education and more specifically Christian-pluralist-multicultural education is a management of Christian values that fosters awareness that peace between religious adherents is a voice raised by lord leaders and us as followers, so that we can and are ready to hear the voice. (perspective) other different religions; respect the significance and dignity of all diverse religious individuals and groups. In other words, to maintain honor and dignity, we do not have to sacrifice the honor and dignity of others, moreover by using means and acts of violence. Mutual respect will lead to mutual sharing among all individuals and groups (Baidhawy, 2002, 2005; Coward, 1989).

\section{Open in Thinking}

Opening up thinking is one of the important goals of education. Therefore, education must be able to empower existing thinking capacities as competencies that can be developed towards maturity to think that are no longer closed or narrow, but open and broad to the various realities around them. If you have never previously thought about other religions, then religious education should adapt Christian education to the existence of other religions as a reality that becomes new knowledge, to be further processed in the process of thinking and acting, criticizing; adopting and/or adapting the truths that exist in other religions as new knowledge that perpetuates the interaction of educators wherever they are.

Because an encounter with another world will generate new interest and enthusiasm in the learning process. Intrinsic learning motivation can also experience strengthening at the level of wanting to explore the religion and culture of other educators or other people in the wider community. The process of maturing from this point of view will manifest in how about what has been learned and what has been understood.
With this new horizon, it is hoped that our Christian educators will be open to rethinking how they see themselves, other people and the world around them. Only then educators could find themselves and new cultures and open new minds. CHRISTIANI-pluralist-multicultural education must be able to condition teachers to meet a plurality of views and challenging radical differences. The result is a willingness to initiate a deepening of self-meaning, identity, world of life, religion and culture of oneself and others (Baidhawy, 2002, 2005; Coward, 1989).

\section{Appreciation and Interdependence}

Baidhawy said that a decent and humane life is only possible in a caring social order, where all members of society can show mutual appreciation and maintain close social relationships, bonds, cohesion and resentment. As social beings (homo socius), humans of any gender and race, even those who claim to be faithful adherents of true individualism, will not be able to survive without social ties. (Baidhawy, 2002, 2005; Coward, 1989).

By this he emphasized that there are many aspects of human life that cannot be overcome materially (Baidhawy language: abundance of wealth, money, throne and wealth). This means that there is a need to help each other on the basis of love and sincerity for fellow human beings, which is born from the awareness of powerlessness, contingency and scarcity, so helping each other is the responsibility of a community or faith community. That a harmonious and dynamic social order will support the actualization of individuals and not for divisions. So, cooperation is important in striving for common welfare, which in turn will also provide for individual welfare. Thus, Christiani-pluralist-multicultural Education needs to share concerns about the appreciation and interdependence of mankindfrom various religious traditions

This is a way of learning to live together that prioritizes community truth. The community truth referred to here is not related to the truth held by a 
particular faith community. For example: Christian or Islamic stand alone. The truth here is the truth along with other religions. How to learn that truth?

In the previous section, it has been explained that in studying religious plurality, in addition to learning to live differently, we must also learn to look for common points that already exist in religious traditions and which we will find in the process of learning together. This means that apart from the scriptural texts, theology and the teachings of inclusive religions that we can explore as a starting point, we can also learn to find something through the process of faith dialogue. Faith that grows and is rooted in social realities, including issues of religious plurality.

So that we are not looking for which truth to dialogue, we better settle for the Christian education of truth that is brought (offered) by our prominent figures, for example for Christians and Muslims: Jesus and Muhammad to serve as models of truth in dialogue. Why are these two figures? Because the Christian community adheres to the truth that is in Jesus, while the Islamic community adheres to the truth that is in Muhammad. Of course, we all acknowledge that the truth in these two figures has undergone a process of internalization in their respective religions, so that the truth has become the truth of the Christian and Islamic communities. Thus, what we share in the dialogue of faith is how Jesus and Muhammad reject various discriminatory attitudes of race, religion or other nations and defend the rights of the weak (poor people) or less fortunate in living their lives

Departing from some of the key concepts above, we can draw a common thread that Christianipluralist-multicultural Education is a process of renewing innovation in religious education in order to instill awareness of the importance of living together in diversity and forging an interdependent relationship in situations where we hear each other, accept different perspectives of religions with an open mind, to find the best way to overcome various conflicts between religions.

\section{Learning Methods}

There are two learning methods that are considered appropriate in Christian-pliralistmulticultural education, namely contextual teaching and learning (CTL) and dialogical methods.

\section{Contextual Teaching and Learning}

CTL is a learning system that helps teachers relate content and real-life contexts. The goal is, by linking the two, the educator will see that everything that is learned is meaningful for his life, so that learning activities become something fun. (Johnson, 2006).

The main characteristic of this learning system is finding meaning. Neuroscientific and philosophical psychological assumptions strongly support this study. Psychologically Fictor E. Frankl, as quoted by Eliane, said that a meaning can be found by: 1) doing work or taking action; 2) living on something, for example: nature and culture or, dealing with other humans in their uniqueness by loving them; and 3) through our attitude toward suffering. From a neuroscience standpoint Diamond and Hopson confirm that the human brain needs meaning. Once the brain finds meaning, physical structures change as the neural connections are formed. And Alfred North Whitehead philosophically said that children should make their ideas their own and understand their application in real life situations, at the same time. This means that the human brain will work to give meaning to new information by connecting existing knowledge and skills. And because the brain is constantly looking for and storing meaningful things, the teaching process must be able to empower the educators in finding meaning. So teaching is to help educators find the content or meaning of what is learned in the context of real life (Johnson, 2006).

The terminology of contextual learning in the CTL learning system refers to a whole consisting of interconnected parts. This definition emphasizes that an idea or thought is not an independent part of the brain. Likewise, action is not an independent part of movements in the body (hands, feet, body, etc.). Both are contextual 
because they are related to form a meaning. Thus, CTL rejects the dualism of traditional education which isolates the abstract side (ideas, concepts, knowledge, information) from the real side of education.

According to him, traditional education tends to collect concepts or ideas in the brain and does not relate how those ideas are meaningful to the life they live. Finally, our educators have a number of savings of concepts or ideas that are in the brain and carried everywhere, but cannot be used because their teacher does not empower the educators about how to connect the text and the context, so the text becomes isolated from the context. Firdaus M. Yunus calls this tendency a fossilized concept, because education is not based on existing social realities (Yunus, 2004).

The advantage of CTL in learning is because it has several principles that really help students understand the content and meaning of learning contextually. These principles are: The principle of dependence and dependence on one another. This principle pays serious attention to human dependence and connectedness with fellow humans in the universe. Because humans are aware of their "being", they are actually aware of their relationships with others. teaching with the principle of dependence and connectedness in the CTL system, we need high correlative abilities.

Because in the application of this principle, the attention of teachers and educators is focused on how the interrelation, dependence and/or connection of all the components involved in teaching and learning activities. Teachers must recognize dependence, linkages in relation to other teachers, with educators, with the material being taught, with the characteristics of the school where the educator learns, with cultural values, customs, patterns of social and religious relations, employment needs, what trend is being followed and so on. The teacher's job is to help (empower) the educators to make connections as an effort to find meaning.

The principle of differentiation; From the symbiosis of life together which depend on one another, we know that humans are not single objects. Mankind are plural, and because they are plural, they are different. Two different entities, when combined, will produce a unique third entity (Johnson, 2006). Teaching with this principle must respect the uniqueness or different entities, but work together in a symbiotic form. So, teachers must believe in the assumptions of modern science which state that the principle of differentiation greatly affects all living systems. Teaching with the CTL system based on this principle must adapt to the workings of the universe. This means that the contextual learning and teaching components that are centered on the activeness of the educators will encourage a unique personal creativity. This way of learning works allows the development of potential, interests, and talents personally and independently.

Principles of self-regulation; teaching is to encourage teachers to unleash their potential. For this purpose, the activities we require from educators are accepting responsibility for their own decisions and behavior, assessing alternatives, making choices, developing plans, analyzing information, creating solutions, and critically assessing evidence. In their relationship with other people, they can join with others to gain new understanding and broaden their horizons. Therefore, they must know themselves (strengths and weaknesses). Self-knowledge in relation to other people is important to complement, enrich and complete each other.

\section{Conclusion}

The results showed that the importance of Christian-pluralist-multicultural education practices in the pluralistic context of North Maluku. From the results of this study, it can be concluded that Christian-pluralist-multicultural education needs to be constructed into a framework of learning practices that accommodate the pluralistic potential. This needs to be done because in the scriptures, our theology and teachings are rich in content of religiousmulticultural plurality. So, let's not reduce it only for certain purposes. We must express this wealth in the internal learning process of religion to be pluralist, and we also make this wealth as capital 
in dialogue with other religions. That the God proclaimed by PK is God who became human, entered into the human Jesus and revealed His love in the real world. Human world. Therefore, His redemptive act departed from the real world. In this real world, all relationships that have been broken (fractured) by $\sin$ are restored or reconciled. All those who become anxious to

\section{References}

[1] Antone, H. S. (2003). Religious Education in Context of Plurality. new Day Publishers.

[2] Baidhawy, Z. (2002). Ambivalensi Agama Konflik \& Nirkekerasan. LESFI.

[3] Baidhawy, Z. (2005). Pendidikan Agama Berwawasan Multikultural. Erlangga.

[4] Bloom, B. S. (1972). Taxonomy of Education Objective: Cognitive and Affevtive Domain. David McKay Company.

[5] Broeree, C. george. (2004). Personality Theories. Prismashopie.kli.,

[6] Bungin, B. (2006). Metodologi Penelitian Kualitatif- Analisis Metodologis ke Arah Ragam Varian Kontemporer. Raja Grafindo Persada.

[7] Candran, R. (1991). Ecclesiology in Context of Religious Pluralism.

[8] Coward, H. (1989). Pluralisme- Tantangan bagi Agama-Agama. Kanisius.

[9] Crain, W. (1992). Theories of Development Concepts and Aplications. New Jersey Prentice Hall.

[10]Creswell, J., \& Creswell, J. (2017). Research design: Qualitative, quantitative, and mixed methods approaches.

[11]El-Ma'hady, M. (2006). Multikulturalisme dan Pendidikan Multikultural.

[12]Haire, J. (1998). Sifat dan Pergumulan Gereja Halmahera 1941-1979. BPK. Gunung Mulia.

[13]Hutabarat, O. R. (2004). Model-Model Pembelajaran Aktif Pendidikan Agama humans, because of their inability to obey all the laws of God which contain love for God and for fellow humans, are given the image of a new relationship in its fulfillment. Therefore, humans are no longer live under the yoke of the Torah (religious law), but in faith in Jesus as a model of righteousness. And in His truth, He teaches many things that are perfect.

Kristen SD, SMP, SMA, berbasis Kompetensi. Bina Media Informasi.

[14] Johnson, E. B. (2006). Contextual Teaching and Learning. Mizan Learning Centre.

[15] Judowibowo Poerwodidagdo. (2003). Yang Terkoyak Konflik Anak-Anak di TobeloGalela. PPRP.

[16] Kadarmanto. (2002). Pendidikan Agama Kristen (PAK) dalam Konteks Masyarakat Majemuk. In R. P. Borong (Ed.), Berakar di dalam Dia dan Dibangun di atas Dia. BPK. Gunung Mulia.

[17]Kristen, D. A. D. B. (1992). Kurikulum lembaga Pendidikan Teologi Program Studi Teologi/Kependetaan program Strata Satu. Depag Bimas Kristen.

[18] Muhamad Ali. (2003). Teologi PluralisMultikultural: merajut kemajemukan, menjalin kebersamaan. Kompas.

[19] Nebraska-Lincoln, J. C.-L. angeles: U. of, \& 2009, undefined. (n.d.). Research design: Qualitative, quantitative, and mixed methods approaches. Belgs.ir. Retrieved February 15, 2020, from http://belgs.ir/imgupl/c75b6f114c23a4d7ea1 1331e7c00e73c.doc

[20]Sitopu, R. (2004). Pendidikan Nilai Bela Rasa Kristiani Sebuah Perspektif Filosofis. Jurnal Teologi Proklamasi -STT Jakarta, 6/.

[21] WilliamBurgess, H. (1975). An Invitation to Religious Education. Religious Education Press.

[22] Yunus, F. M. (2004). Pendidikan Berbasis Realitas Sosial. Logung Pustaka. 